\title{
Understanding speech rights: defensive and empowering approaches to the First Amendment
}

\section{Laura Stein}

Department of Radio-Television-Film, University of Texas at Austin

\section{Rethinking First Amendment theory}

The configuration of speech rights in contemporary media systems is a vital concern for democratic societies. Rights demarcate opportunities for individual and collective action, and protect the conditions necessary to democratic societies (Bobbio, 1987). As the ultimate arbiter of who can speak in the media and the conditions under which they can do so, speech rights frame the possibilities and limits for democratic speech in contemporary communication systems. Since media act as critical forums for public opinion formation (Garnham, 1990; Habermas, 1962/1991) and influence public perception of political and social reality (Graber, 1984; Iyengar and Kinder, 1982; Kraus and Davis, 1976), understandings of speech rights in these forums are highly significant.

The question of how to understand speech rights in the US media is ripe for re-evaluation. Contemporary speech regimes governing media law are unravelling due to media convergence. Speech rights in the media traditionally have been determined according to whether a media system operates within a print, broadcast or common carrier framework. While the print model assumes that the speech rights of media owners are inviolate, the broadcast model permits the government to balance the speech rights of the broader public against those of media owners. The common carrier model, which applies to telephones, treats media owners as mere conduits of information with no associated speech rights. These divergent speech regimes are being called into question by new media systems and services, such as cable television, direct broadcast satellites and computer networks, which blur the boundaries between media once thought to be

Media, Culture \& Society (C) 2004 SAGE Publications (London, Thousand Oaks and New Delhi), Vol. 26(1): 103-120; 039495

[ISSN: 0163-4437 DOI: 10.1177/0163443704039495] 
technologically discrete and distinct. These hybrid or convergent media highlight the inadequacy of tying speech rights to media forms and characteristics, and demand a rethinking of speech rights theory.

Divergent speech regimes are also the product of conflicting interpretations of the First Amendment to the Constitution, the principal guarantor of speech rights in the USA. The First Amendment states, 'Congress shall make no law . . . abridging freedom of speech, or of the press' (Constitution of the United States of America, 1791/1979: 31). Despite their apparent clarity, these words have engendered radically different understandings of speech rights. Scholars generally account for these differences by pointing to one of two normative distinctions found in dominant interpretive traditions of First Amendment law. One view states that legal analysis divides over whether the First Amendment should be seen as an absolute or conditional prohibition on state action (Horwitz, 1991: 22; Smolla, 1993; Sunstein, 1993: 5). In this explanation, First Amendment interpretations hinge on normative views of state action in which the state is seen either as never justified in regulating speech or as occasionally permitted to impose reasonable regulations under some conditions. The other view attributes differences in First Amendment law to conflicting normative conceptions of the relationship between individuals and society. In this account, the courts choose either to protect individual autonomy from government interference or to enable government action that promotes the exchange of information and debate among social collectives (Fiss, 1986; Parsons, 1987). While both accounts pinpoint salient distinctions between current views of speech rights, neither offers a systematic view of the relationship between speech rights and normative democratic theory. Yet, a more systematic and comprehensive account of this relationship is precisely what is necessary if we are to understand both how speech rights have been interpreted in the past and how they might best be interpreted in the future.

In this article, I endeavour to re-evaluate the relationship between speech rights, media systems and democratic communication. A logical place to begin this re-evaluation is with liberal democratic theory, the dominant and long-standing tradition within US political thought. Concerned primarily with the protection of individual rights and the maintenance of a democratic system of governance (Held, 1987; Holden, 1988; Miller, 1991), liberal democratic theory provides a philosophical foundation for a more comprehensive understanding of speech rights. This understanding encompasses not only normative views of the relationship between individual and society and of the role of state action, but also normative definitions of freedom and its relationship to extant social conditions. Drawing on key liberal political theorists, such as Locke, Mill, Nozick, Friedman, Hayek, Green, Dewey and Barber, I advance the notion that two conflicting views of speech rights coexist within liberal democratic thought. These views, 
which themselves stem from divergent intellectual traditions within liberalism, are labelled 'defensive' and 'empowering'. Briefly stated, the defensive approach to speech rights presumes that freedom exists in privately controlled spaces that have been secured against government coercion, while the empowering approach holds that freedom exists in public spaces in which individuals find actual opportunities to speak free from both governmental and non-governmental coercion. After reviewing the principal tenets of each approach, I demonstrate how defensive and empowering theories of speech rights are manifest in, and reinforced by, legal understandings of the First Amendment. Specifically, I analyse their role in two Supreme Court cases widely recognized as pivotal in determining print and broadcast speech regimes, Red Lion Broadcasting Co. v. Federal Communications Commission (1969; henceforth Red Lion) and Miami Herald Publishing Co. v. Tornillo (1974; henceforth Tornillo). I conclude by arguing that empowering speech rights offer the best foundation for democratic communication, and by proposing a set of philosophically determined legal principles capable of revitalizing the meaning and function of speech rights in the USA.

\section{Liberal democratic theory and speech rights}

Liberal democrats agree that speech rights are a fundamental human liberty and that access to a wide range of information, opinion and expression is a prerequisite for legitimate democratic decision-making. Yet, contained within liberal democratic thought are two traditions that differ sharply over how to achieve these ends. These two traditions, neoliberalism - with roots in classical liberalism - and participatory democratic theory, invoke competing philosophical assumptions about the core questions underlying determinations of speech rights. These questions include the nature of the individual's relationship to society, the meaning of liberty or freedom, the proper domain of state action and the necessity of examining the real conditions surrounding speech. The end result is that two fundamentally distinct conceptions of speech rights emerge from within liberalism.

\section{Neoliberalism and the defensive approach to speech rights}

The defensive approach to speech rights can be traced from its early appearance in the works of classical liberals, such as Locke and Mill, through its present incarnation in the neoliberal thought of Nozick, Friedman and Hayek. Classical liberals argued for restrictions on state power and for private spheres of activity free from state intervention as a means of protecting civil society from autocratic political systems (Held, 
1987: 41). Locke (1688/1996), the founder of modern liberalism, maintained that individuals enter into society to protect pre-existing rights and interests. While government may be called upon to protect rights from the transgressions of others, government regulation should be limited to maintaining private spaces in which individuals are left to themselves. Liberty, defined as the absence of coercion, would flourish in private spaces where strict limits on state action and laissez-faire economic policies prevailed. Applying these ideas to the question of speech rights specifically, Mill (1859/1993) argued that prohibiting government interference with expression and relying on the public's self-restraint in matters of non-governmental censorship could secure freedom of speech.

As with classical liberalism, neoliberalism is concerned with defining the limits of state power and with maintaining private spaces in which individuals can pursue their goals with minimal state intervention (Held, 1987: 244). Neoliberals follow Locke in asserting that individuals possess inherent rights that it is the duty of government to protect (Friedman, 1962: 2; Hayek, 1960, 1944/1962; Nozick, 1974: 14-19). Like classical liberalism, neoliberalism defines liberty as the absence of coercion by government and by others (Friedman, 1962; Hayek, 1960, 1944/1962; Nozick, 1974). Finally, in addition to sharing the main tenets of classical liberalism, neoliberalism further explores the essential role markets play in creating and maintaining private spheres of freedom.

According to neoliberals, liberty exists in private spaces in which individuals are free to enact their will when circumstances permit. Markets are ideal spheres for individual liberty, and the relationship between markets and liberty is iterative. Liberty is both a precondition and an outcome of competitive markets. On the one hand, a well-functioning economy requires that individuals be able to draw on their knowledge and experience to respond to changing social conditions (Friedman, 1962: 4; Hayek, 1960, 1944/1962). Individuals require liberty to act in a marketplace that permits the unplanned coordination of economic activity. Liberty is also the result of competitive markets that decentralize power among a plurality of individual decision-makers (Friedman, 1962: 12-13) and constitute a neutral space in which individuals may exercise their will. Thus markets are coercion-free, and marketplace decisions are superior to decisions made by governments because the state has no legitimate reason to interfere with individual actions (Nozick, 1974: 262-4) and because government power threatens liberty (Friedman, 1962: 15). For neoliberals, the primary function of the state is to maintain a private sphere of individual liberty, and the state can do so by generally ensuring the conditions necessary to a competitive market economy (Friedman, 1962: 4; Hayek, 1944/1962: 35).

Proponents of communication industry deregulation draw on neoliberal theory to argue that speech rights and opportunities should be determined 
by 'neutral' market mechanisms rather than by government policymakers (Fowler and Brenner, 1982; Kelley and Donway, 1990). For neoliberals, emphases on the need to maintain individual rights against society, liberty as the absence of direct coercion and strict limits on government action combine to produce a defensive view of speech rights. Neoliberal theory suggests that government has no role to play in fostering democratic speech. From this perspective, free speech is best served by market mechanisms that are identified with a private sphere of public opinion formation. Thus, Friedman (1962: 35) can argue that federal regulation of radio and television oversteps the government's primary role of maintaining markets and thereby constitutes 'implicit censorship and violation of free speech'. Whether or not the majority of individuals find real opportunities to exercise free speech is inconsequential to the defensive view of speech rights that assumes that governments alone, and never competitive markets, have the power to coerce.

\section{Participatory democratic theory and the empowering approach to speech rights}

Participatory democratic theory, as expressed in the writings of Green, Dewey and Barber, contains a formidable critique of classical liberalism and neoliberalism, as well as an alternative view of speech rights. This tradition redefines the terms and tenets of liberal democratic theory, particularly the definitions and functions of liberty, theories of state action and the conditions necessary to democratic communication. Taken together, the work of Green, Dewey and Barber supports an empowering view of speech rights that is grounded in a philosophical and pragmatic assessment of the role of speech in democratic societies.

T.H. Green provides a foundation for this revision of liberal theory (Holden, 1988: 80; Sabine, 1973: 368), as well as for empowering speech rights. Green (1881/1991: 21) argued that liberty is only possible when social conditions permit individuals to act on their will and capacities. Liberty requires freedom from coercion, as well as freedom to act in the social world. Green further observed that coercion is not the sole province of the state. Rather, economic and social conditions may also pose significant threats to individual liberty or freedom. In such cases, the state should play an affirmative role in promoting the conditions necessary to freedom. The state must make it possible for individuals to realize both their own and the common good through unobtrusive regulations which permit, but never compel, individual actions (Green, 1879-80/1967: 45).

Green's revision of liberalism is incorporated and extended in the work of American pragmatist philosophers Dewey (1927/1954) and Barber (1984), both of whom construct a vision of liberalism dedicated to 
participatory democratic processes. ${ }^{1}$ Both Dewey and Barber assert that political rights and freedoms are maintained not against, but rather through, society. Both view rights as mutually agreed-upon social constructs that accord individuals possibilities and protections they would otherwise lack. Rather than stressing the alienation of individuals from the government, Dewey and Barber argue that democratic publics and the state are theoretically coterminous. Democratic states exist not only to protect their citizens from coercion, but also to provide an instrument through which citizens collectively examine, make and enact social decisions to benefit the common good.

Both Dewey and Barber assign communication a central role in democratic processes. Communication facilitates processes of social inquiry and mediation that generate the political and social knowledge necessary to legitimate self-governance (Barber, 1984: 13; Dewey, 1927/1954: 155). Social mediation, which enables democratic deliberation and decisionmaking, requires the circulation of the full range of the public's insights, experiences and perspectives. Citizens must be able to express their views and have these views heard by others. This type of communication is necessary if citizens are to think as a public, to make reasoned political judgments, and to democratically structure the consequences of a life in common (Barber, 1984: 197).

Participatory democracy aims to ensure the conditions that make it possible for all citizens to actively engage in the political arena and in the process of social mediation. Unlike neoliberal theorists, who define rights and liberties without reference to actual social and political conditions, participatory democrats recognize that any definition of liberty must be sensitive to the historical and social contexts that affect its real life applications. Consequently, both Dewey and Barber are concerned that citizens in a democracy be able to utilize existing communication systems for democratic ends. For Dewey (1927/1954: 168), democratic communication requires an understanding of speech rights that provides real opportunities for public participation in democratic processes on a scale commensurate with the consequences of associated life. For Barber (1984: 273-9), democracies must support local and national institutions and forums that enable communities to mediate between themselves and to engage in a full range of democratic speech.

Participatory democratic theory suggests an empowering approach to speech rights. This approach recognizes the constructed nature of rights, defines liberty as the opportunity to act and requires governments to ensure that these opportunities exist within a given set of social conditions. Concentrating on the need to develop procedures, processes and institutions that support the acquisition of social knowledge and legitimate public decision-making, participatory democratic theory outlines the communicative requirements of democratic societies. These requirements include 
the maintenance of communication systems which enable social mediation, the availability of communicative spaces that are free from coercion of all kinds and a democratic state that is authorized to secure these conditions.

\section{New readings of old cases}

Threads of neoliberal and participatory democratic theory run through law and policy debates surrounding the First Amendment. These divergent traditions of liberal democratic theory condition how social conflicts over speech rights are interpreted, framed and decided within the legal arena. Consider, for example, the way two Supreme Court cases seminal to the development of print and broadcast speech regimes make use of the philosophical assumptions behind defensive and empowering speech rights. Both cases, Red Lion Broadcasting Co. v. Federal Communications Commission (1969) and Miami Herald Publishing Co. v. Tornillo (1974), examined the public's right to send and receive information in the media, two integral components of social mediation. Yet, in each case the Court drew on a different liberal democratic tradition to reach opposite conclusions regarding the appropriate configuration of speech rights in print and broadcast media.

\section{Red Lion and empowering speech rights}

In Red Lion, the Supreme Court was asked to determine the constitutionality of federal communication policies designed to promote the public's right to receive balanced information. The case involved the Federal Communication Commission's (FCC) now defunct Fairness Doctrine, which required that broadcasters air fair coverage of controversial issues of public importance (Fairness Doctrine and Public Interest Standards, 1974). Also under scrutiny were two rules, closely related to the Fairness Doctrine, which mandated that broadcasters give a right of reply to the subjects of personal or political attacks (Personal Attacks; Political Editorials, 1969, cited in Red Lion, 1969: 373-5; Report on Editorializing by Broadcast Licenses, 1949). ${ }^{2}$ The Doctrine and its corollaries asserted a limited claim on behalf of the public for speech rights in broadcasting. The FCC had designed these policies to ensure that broadcasters fostered informed public opinions, promoted 'freedom of speech . . . for the people of the Nation as a whole', and refrained from imposing restraints on the public's speech rights (Report on Editorializing by Broadcast Licenses, 1949: 1248-9).

In a unanimous decision, the Red Lion Court declared the Fairness Doctrine and its corollaries constitutionally sound. The Court offered two 
reasons for its decision. First, the FCC was authorized by Congress to implement reasonable rules and regulations in the public interest, and, second, the Doctrine and its component rules served to enhance rather than to abridge the First Amendment rights of the public and the press (Red Lion, 1969: 375). The Court also linked its decision to spectrum scarcity in broadcasting, arguing that the paucity of broadcast opportunities on a publicly held resource, as well as government licensing of that resource, necessitates that the public retain some First Amendment rights over this medium (Red Lion, 1969: 30). Textbook readings of the case generally attribute the Red Lion decision to the Court's perception of spectrum scarcity (Gillmor et al., 1998: 676; Middleton et al., 1997: 527). Yet, spectrum scarcity can only become a factor once the Court decides that the real conditions in which broadcasting operates are relevant to its analysis of speech rights. Indeed, a closer reading of the case suggests that the Red Lion decision is not the product of a mid-range theory about spectrum scarcity, but rather of a particular political philosophy of democratic communication. In setting forth its opinion, the Court made use of several tenets of participatory democratic theory. The Court maintained that the government might act to affirmatively promote speech rights, that nongovernmental actors are capable of coercion and that the real conditions influencing speech opportunities are relevant to determinations of speech rights.

The Court rejected the contention that all state action constitutes censorship. In the case of broadcasting, the Court argued, government regulation promotes speech rights in several ways. First and foremost, government regulation and rationalization of broadcast spectrum is a necessary prerequisite to the effective use of the medium (Red Lion, 1969: 376). Without the government regulation of otherwise chaotic spectrum space, no one would be able to speak or be heard over the airwaves. Additionally, regulations like the Fairness Doctrine crafted an appropriate balance between the speech rights of broadcasters and the public. According to the Court, the public status of the airwaves, as well as the government's role in allocating licenses, bestowed speech rights on the broader public. By allocating licenses while simultaneously requiring license-holders to adhere to public interest regulations, the government was thought to preserve and promote the speech rights of all parties. Finally, the Court made a distinction between government policies that enhance, and those that inhibit, free speech. The fairness rules enhanced speech rights by ensuring that the public received balanced information on controversial issues without proscribing or prescribing any specific broadcast content (Red Lion, 1969: 396).

The Court also argued that the government could act to protect the public's speech rights from infringement by private, non-governmental censors. Citing Associated Press v. United States (1945), a case that had 
supported government sanctions against private actors who obstructed freedom of expression, the Court noted that broadcasters' speech rights did not include 'a right to snuff out the free speech of others' (Red Lion, 1969: 388). The Court said:

There is no sanctuary in the First Amendment for unlimited private censorship operating in a medium not open to all. 'Freedom of the press from governmental interference under the First Amendment does not sanction repression of that freedom by private interests.' (Associated Press, 1945, cited in Red Lion, 1969: 393)

Red Lion recognized the ability of private actors to obstruct the speech rights of others, as well as the responsibility of the government to protect the public's rights against the coercive power of broadcasters (Red Lion, 1969: 390).

Finally, the Red Lion Court was willing, albeit in a limited manner, to acknowledge the real world conditions in which broadcast speech operates and to interpret speech rights in light of these conditions. The Court granted limited speech rights to those who are denied a license to utilize a scarce public resource subject to technical market failure (Red Lion, 1969: 399-400). The Court reasoned that, as long as the government is in the position to grant broadcast licenses to some while denying others, it is justified in mandating fairness. The Court explicitly declined to consider whether other types of market failure might necessitate the protection of public speech rights in the broadcast media. However, its assertion that the law must determine speech rights in light of the context of scarce, government-licensed spectrum space resonated with an empowering approach to speech rights.

\section{Tornillo and defensive speech rights}

The philosophical assumptions underpinning Red Lion contrasted sharply with those of Tornillo. In Tornillo, the Court examined the constitutionality of a Florida statute that gave political candidates a direct right of reply to newspapers that had maligned them during an election. ${ }^{3}$ The case served as a testing ground for a theory of media access advanced by Tornillo's lawyer, Jerome Barron. Barron believed that the real conditions of commercial media markets failed to support speech rights. According to Barron (1967: 1646), commercial media were economically compelled to cater to large audiences, to avoid offending advertisers, and to refrain from airing controversial or unpopular ideas that might adversely affect their business. Without a constitutional right of access, he argued, speech rights would be a reality for media owners, but not for the majority of people who lacked opportunities to speak in the dominant media of their era. In 
Tornillo, Barron argued that the government should enforce the Florida statute as a means of safeguarding fair elections, an informed electorate and the dissemination of information about important public issues (Brief for Appellee Pat L. Tornillo Jr, 1973).

Although the Supreme Court had upheld the Fairness Doctrine in broadcasting, it unanimously rejected the Florida statute as a violation of the First Amendment rights of the print media. The Court gave several reasons for its decision. First, the justices stated that compelling newspapers 'to publish that which "reason" tells them should not be published' is no different from censoring newspaper content (Tornillo, 1974: 257). Both acts were perceived as impermissible government restraints on free speech. Second, the Court viewed the statute as a content-based restriction on the free press rights of newspapers that might cause newspapers to avoid potentially controversial speech (1974: 258). Third, the Court claimed that the statute authorized an unconstitutional intrusion on the function of newspaper editors (1974: 259).

Though ostensibly informed by legal absolutism, the Tornillo Court's decision makes use of a broadly defensive approach to speech rights. The Court rejected the claim that an economically based scarcity of speech opportunities justified government regulation or correction (Barron and Dienes, 1993: 393; Van Alstyne, 1984: 86). The justices reviewed the arguments of Tornillo, including the charges that the newspaper industry had become monopolistic, anti-competitive and highly concentrated; that entry into the newspaper market was prohibitively expensive; and that citizens generally lacked the means to participate in contemporary public debate (Tornillo, 1974: 250-4). After recounting these arguments at length, the Court quickly dispensed with them in its subsequent analysis. ${ }^{4}$ Whether or not these conditions did in fact prevail, said the Court, had no bearing on considerations of speech rights because any corrective mechanism necessarily involved government coercion (1974: 255).

The Tornillo Court categorically dismissed government remedies as legitimate solutions to scarce speaking opportunities in the newspaper market. According to the Court, such solutions were pre-empted by the fact that government action and government coercion are synonymous.

The implementation of a remedy such as an enforceable right of access necessarily calls for some mechanism, either governmental or consensual. If it is governmental coercion, this at once brings about a confrontation with the express provisions of the First Amendment ... (Tornillo, 1974: 255)

Given its conflation of government mechanisms with government coercion, the Court could not recognize the critical distinction made in Red Lion between government actions that abridge or enhance speech rights. For the Tornillo Court, a press left to the exigencies of the marketplace was preferable to government policies inherently equated with coercion. 
In addition, while the Red Lion Court had considered the First Amendment rights of both the public and broadcasters, the Tornillo Court addressed only those of newspapers. The Florida statute had suggested a view of speech rights that included the right of political candidates to provide information about their candidacy, the right of citizens to receive a range of information about political candidates, and the authority of the government to promote fair elections and an informed electorate. However, rather than evaluate the multiple speech interests involved or attempt to craft a balance between potentially conflicting interests, the Tornillo Court focused its attention on the speech rights of newspapers (Tornillo, 1974: 244). As long as the newspaper was left alone, speech rights were operative. The Court's myopia was made possible by its belief that, in the absence of government coercion, the rights of all parties were adequately protected.

Red Lion and Tornillo established different speech regimes for print and broadcast media. What distinguishes these cases in the first instance is not the ostensible differences between the technological characteristics of print and broadcast, but rather the philosophical assumptions that frame the Courts' analyses of speech rights. The reason why technical market failure counts in broadcast, while economic market failure fails to count in print, is that an empowering approach to speech rights permits the Court to look at the real conditions in which speech rights operate while the defensive approach does not. Furthermore, while an empowering approach acknowledges that government action may be necessary to protect the speech rights of the broader public, the defensive approach admits no conceivable justification for government-created speech opportunities beyond those supplied by the market.

\section{Reinvigorating the First Amendment}

Under a defensive approach, First Amendment law is incapable of protecting speech rights when markets fail to distribute communication resources widely or equitably. Participatory democratic theory finds this approach inadequate for democratic societies that need to ensure real opportunities to engage in social mediation in contemporary communications systems. For this reason, I suggest here that the future of democratic communication depends upon the rejection of the faulty logic of neoliberalism and the adoption of an alternative set of policy principles to guide interpretations of speech rights. These principles, which accord with the central tenets of participatory democratic theory, are (1) the government has a compelling interest in protecting and promoting democratic speech, (2) the First Amendment must be interpreted in light of the real conditions affecting democratic speech, (3) the media have a public function in 
democratic societies and (4) hybrid regulatory models are an acceptable means of protecting democratic speech in contemporary media systems.

The government has a compelling interest in protecting democratic speech

Participatory democratic theory suggests that the government has a compelling interest in being able to implement content-neutral policies that protect democratic speech. While the state itself is a potential censor, it is also an agent of the public capable of protecting rights from a variety of coercive forces. Participatory democratic theory calls on the state to promote speech rights when widespread opportunities to engage in social mediation do not otherwise exist. However, state action must be carried out in a contentneutral way that enhances, but does not abridge, democratic speech rights. The notion that the government has a compelling interest in maintaining democratic communication systems is a critical starting point for reforming First Amendment law. In addition to permitting the government to act affirmatively to guarantee speech rights, this policy principle enables the courts to better analyse standard First Amendment legal tests that ask whether the regulation of speech is narrowly tailored to serve an 'important' or 'compelling' government interest. ${ }^{5}$

The First Amendment must be interpreted in light of the real conditions affecting democratic speech

In order to support democratic processes, communication systems must act as a means of expression for the broader citizenry at least some of the time. Interpretations of speech rights that eschew analysis of the real conditions that shape opportunities for democratic speech do a profound disservice to democratic societies. An empowering approach to speech rights insists that governments consider all factors - whether social, economic or technological in origin - which inhibit speech in contemporary communication systems. In addition, governments must formulate policies that mitigate the harmful effects of both governmental and non-governmental sources of coercion. To this end, Emerson (1970:15) and Sunstein (1993: 18-19) have proposed that understandings of speech rights be based on whether or not they create an effective system of freedom of expression in a particular social context. In order to maintain a system of free speech, governments must create a workable structure of principles, practices, institutions that respond to real conditions and which advocate realistic goals. 


\section{The media have a public function in democratic societies}

Historically, the US has required its communication systems to perform a dual role. The media are economic enterprises that must succeed within market systems. At the same time, they are political entities enmeshed in the processes and institutions of democratic systems. As such, media inevitably have a public function in democratic societies. Barron (1967: 1669) argues that the public function of the media warrants that the law grants them a quasi-public status. This status is necessary if media are not to be treated simply as private property over which only media owners have rights. As Schiller (1989: 171) notes, information and communication are critical national resources that cannot be left entirely to private and unaccountable domains. According to this policy principle, the public's speech rights should not be confined exclusively to public property, but must be applicable to all spaces that have a public function.

\section{Hybrid regulatory models can protect democratic speech in contemporary media systems}

With the advent of new technologies, greater bandwidth and sophisticated compression technology, media systems increasingly convey information to consumers over multiple channels or lines. Most cable systems offer 60 or more channels (Broadcasting and Cable Yearbook, 2001: xxx), direct broadcast satellites deliver upwards of 150 channels (Morgan, 1994: 32-3), and the possibilities for distributing content and services over the Internet are likewise great. With compression technology, even broadcasters will be able to increase the amount of programming they provide on their current spectrum allocation. In this multichannel media environment, regulatory models that blend different aspects of traditional speech regimes serve to balance the interests of media owners with those of the broader public.

For example, cable television has been regulated along a hybrid model since the late 1960s. Arguing that one party should not control the content of so many channels into the home (First Report and Order, 1969: 205), the FCC developed a speech regime for cable that drew on various aspects of print, broadcast and common carrier regulation. While cable operators were given speech rights over the majority of their channels, other channels were deliberately shielded from the operators' control in order to protect the ability of third parties to act as independent sources of information over this multichannel medium. Unfortunately, while the Supreme Court has allowed this hybrid regulatory model to stand over the years, it has been uncomfortable doing so. This discomfort is itself an artefact of the dominance of the defensive approach to speech rights in communication law (Stein, 2000). Nevertheless, societies that aim to protect democratic 
speech should develop hybrid regulatory models to govern technologies that are increasingly capable of providing multiple channels and performing multiple roles. Hybrid regulatory models allow democratic communication forums to coexist with forums devoted exclusively to media operator speech, and as a result everyone's speech rights are protected.

\section{Conclusion}

Critical legal studies scholars argue that the acceptance or rejection of one legal theory over another ultimately turns on the selection of one normative theory over another (Gordon, 1990; Kairys, 1990; Unger, 1986). The notion that all law relies on a normative theory of social or political organization is the necessary starting point both for criticism of traditional legal scholarship and for the construction of alternative legal theories and principles. Although the aforementioned policy principles portend a significant change in how speech rights are presently understood, this change requires little more than the Court's rejection of neoliberalism and acceptance of participatory democratic theory as the guiding philosophical framework for its analyses of speech rights.

Participatory democratic theory provides an understanding of speech rights best able to serve democratic societies. According to this theory, speech rights must support communicative processes that allow citizens to mediate their unique experiences and perspectives, thereby developing the knowledge necessary to self-governance. This view of communication differs from the neoliberal perspective, which assumes that social knowledge is created when individuals transmit autonomous and pre-existing ideas to one another (Peters, 1989). Participatory theory subscribes to what Carey $(1988: 15,18)$ terms a 'ritual view' of communication, or one that identifies communication with processes of sharing and participation, and rejects a 'transmission view' which defines communication as 'imparting', 'transmitting' or 'giving information to others'. By definition, social mediation is not something that originates in one source or set of sources to be imparted to the masses, but must encompass the mutual exchange of insights and opinions among the broader public.

While neoliberal theorists are generally content to let speech opportunities be decided by market mechanisms, participatory democrats recognize that the exercise of rights requires spaces that are free from coercion of all types. These spaces can be opened up through public law and legislation. Whether situated within publicly or privately supported communication systems, it is critical that these spaces be defined by their commitment to the implementation of democratic processes (Mosco, 1996: 170). Thus, while these spaces are secured by the state, they are not the objects of state control. The state must make it possible for individuals to exercise their 
speech rights without restriction or compulsion by either public or private agents, and it must implement neutral policies and laws that function in a predictable and unobtrusive manner.

In this article, I argue that conflicting understandings of speech rights relate directly to central conflicts within liberal democratic thought itself. Debates over the meaning of liberty or freedom, the proper role of state action and the conditions necessary to democratic communication are not discrete conceptual dilemmas, but are integrated aspects of comprehensive theories of democracy and democratic speech rights. For this reason, investigations into the normative meaning and function of speech rights must begin at the fundamental level of political philosophy. As I have shown, liberal political philosophy provides a framework from which to understand competing conceptions of speech rights, as well as to assess the ultimate desirability of one view of speech rights over another.

\section{Notes}

1. Pragmatists focus on the epistemological processes by which humans determine concepts of truth and knowledge. Within this tradition, democracy is viewed as a method for collective deliberation.

2. The Fairness Doctrine was a casualty of the deregulatory fervour of the FCC of the 1980s. The FCC dropped the Doctrine in 1987 after the Supreme Court decided, in Meredith Corp. v. Federal Communications Commission, that Congress had never codified the rule and that the FCC could repeal the Doctrine if it were no longer determined to be in the public interest. The FCC, under Chairman Michael Powell, dropped the personal attacks and political editorializing rules over a decade later.

3. The Florida statute, enacted in 1913, made it a misdemeanour for a newspaper to print an attack on the personal character of a political candidate without offering the candidate an equally prominent space in which to reply (Newspaper Assailing Candidate in an Election: Space for Reply, 1973).

4. While the arguments of access advocates are recounted in three pages, they are dismissed in one paragraph and the Court's rationale for deciding in favour of the Miami Herald is accomplished in two brief pages.

5. Respectively, these are referred to as the 'intermediate scrutiny' and 'strict scrutiny' tests.

\section{References}

Associated Press v. United States, 326 US 1 (1945).

Barber, B. (1984) Strong Democracy: Participatory Politics for a New Age. Berkeley: University of California Press.

Barron, J. (1967) 'Access to the Press - A New First Amendment Right', Harvard Law Review 80(8): 1641-78. 
Barron, J. and T. Dienes (1993) First Amendment Law in a Nutshell. St Paul, MN: West Publishing.

Bobbio, N. (1987) The Future of Democracy: A Defense of the Rules of the Game. Cambridge: Polity.

Brief for Appellee Pat L. Tornillo Jr, No. 73-797 (1973, October Term) Filed with the Supreme Court of the United States in Miami Herald Publishing Co. v. Tornillo.

Broadcasting and Cable Yearbook (2001) New Providence, NJ: Bowker Publications.

Carey, J. (1988) Communication as Culture: Essays on Media and Society. Boston: Unwin Hyman.

Constitution of the United States of America (1791/1979) House Document No. 96-143, United States Government Printing Office.

Dewey, J. (1927/1954) The Public and Its Problems. Athens, OH: Ohio University Press.

Emerson, T. (1970) The System of Freedom of Expression. New York: Random House.

Fairness Doctrine and Public Interest Standards, 39 Fed. Reg. 26372 (1974).

First Report and Order, 20 FCC 2d 201 (1969).

Fiss, O. (1986) 'Free Speech and Social Structure', Iowa Law Review 71(5): $1405-25$.

Fowler, M. and D. Brenner (1982) 'A Marketplace Approach to Broadcast Regulation', Texas Law Review 60: 207-57.

Friedman, M. (1962) Capitalism and Freedom. Chicago, IL: University of Chicago Press.

Garnham, N. (1990) Capitalism and Communication. London: Sage Publications.

Gillmor, D.M., J.A. Barron and T.F. Simon (1998) Mass Communication Law: Cases and Comment, 6th edn. Belmont, CA: Wadsworth Publishing Co.

Gordon, R. (1990) 'New Developments in Legal Theory', pp. 415-26 in D. Kairys (ed.) The Politics of Law: A Progressive Critique. New York: Pantheon Books.

Graber, D. (1984) Mass Media and American Politics. Washington, DC: Congressional Quarterly Press.

Green, T. (1879-80/1967) Lectures on the Principals of Political Obligation. Ann Arbor, MI: University of Michigan Press.

Green, T. (1881/1991) 'Liberal Legislation and Freedom of Contract', pp. 21-32 in D. Miller (ed.) Liberty. New York: Oxford University Press.

Habermas, J. (1962/1991) The Structural Transformation of the Public Sphere: An Inquiry into a Category of Bourgeois Society. Cambridge, MA: MIT Press.

Hayek, F. (1944/1962) The Road to Serfdom. Chicago, IL: University of Chicago Press.

Hayek, F. (1960) The Constitution of Liberty. London: Routledge and Kegan Paul.

Held, D. (1987) Models of Democracy. Stanford, CA: Stanford University Press.

Holden, B. (1988) Understanding Liberal Democracy. Hemel Hempstead: Philip Allan.

Horwitz, R. (1991) 'The First Amendment Meets Some New Technologies: Broadcasting, Common Carriers, and Free Speech in the 1990s', Theory and Society 20: 21-72.

Iyengar, S. and D. Kinder (1982) News That Matters. Chicago: University of Chicago Press.

Kairys, D. (1990) 'Introduction', pp. 1-9 in D. Kairys (ed.) The Politics of Law: A Progressive Critique. New York: Pantheon Books. 
Kelley, D. and R. Donway (1990) 'Liberalism and Free Speech', pp. 60-101 in J. Lichtenberg (ed.) Democracy and the Mass Media. Cambridge: Cambridge University Press.

Kraus, S. and D. Davis (1976) The Effects of Mass Communication on Political Behavior. University Park Pennsylvania State University.

Locke, J. (1688/1996) 'Second Treatise on Government', pp. 243-79 in M. Cohen and N. Fermon (eds) Princeton Readings in Political Thought. Princeton, NJ: Princeton University Press.

Miami Herald Publishing Co. v. Tornillo, 418 US 241 (1974).

Middleton, K.R., B.F. Chamberlin and M.D. Bunker (1997) The Law of Public Communication, 4th edn. Menlo Park, CA: Longman.

Mill, J. (1859/1993) On Liberty. New York: Bantam Books.

Miller, D. (1991) 'Introduction', pp. 1-20 in D. Miller (ed.) Liberty. New York: Oxford University Press.

Morgan, W. (1994) 'DBS Satellites: Inside and Out', Satellite Communications 18(5): $32-3$.

Mosco, V. (1996) The Political Economy of Communication: Rethinking and Renewal. Thousand Oaks, CA: Sage Publications.

Newspaper Assailing Candidate in an Election: Space for Reply, Florida Statute $\S 104.38$ (1973).

Nozick, R. (1974) Anarchy, State and Utopia. New York: Basic Books.

Parsons, P. (1987) Cable Television and the First Amendment. Lexington, MA: Lexington Books.

Personal Attacks; Political Editorials, 47 CFR $\S ~ 73.123,73.300,73.598,73.679$ (1969).

Peters, J. (1989) 'John Locke, the Individual, and the Origin of Communication', Quarterly Journal of Speech 75(4): 387-99.

Red Lion Broadcasting Co. v. Federal Communications Commission, 395 US 367 (1969).

Report on Editorializing by Broadcast Licenses, 13 FCC 1246 (1949).

Sabine, G. (1973) A History of Political Theory, 4th edn. Hinsdale, IL: Dryden Press.

Schiller, H. (1989) Culture Inc.: The Corporate Takeover of Public Expression. New York: Oxford University Press.

Smolla, R. (1993) Free Speech in an Open Society. New York: Vintage Books.

Stein, L. (2000) 'Can the First Amendment Protect Public Space on U.S. Media Systems? The Case of Public Access Television', Communication Law and Policy 5(3): 349-83.

Sunstein, C. (1993) Democracy and the Problem of Free Speech. New York: The Free Press.

Unger, R. (1986) The Critical Legal Studies Movement. Cambridge, MA: Harvard University Press.

Van Alstyne, W. (1984) Interpretations of the First Amendment. Durham, NC: Duke University Press.

Laura Stein is an Assistant Professor in the Radio-Television-Film Department at the University of Texas at Austin. She writes about communication law and policy, political communication, speech rights and 
communication technologies. Her work has appeared in Communication Law and Policy, the Sage Handbook of New Media and Javnost/The Public. Address: Department of Radio-Television-Film, University of Texas at Austin, CMA 6.118, Austin, TX 78712, USA.

[email: LStein@mail.utexas.edu] 